\title{
Surveyor
}

\section{The Town Planning Aspect of Subdivisions}

\section{E.H. Cowdery}

To cite this article: E.H. Cowdery (1918) The Town Planning Aspect of Subdivisions, Surveyor, 31:6, 165-171, DOI: 10.1080/18324460.1918.10439440

To link to this article: http://dx.doi.org/10.1080/18324460.1918.10439440

曲 Published online: 01 Aug 2012.

Submit your article to this journal tra

LII Article views: 3

Q View related articles $\asymp$ 


\section{The Town Planning Aspect of Subdivisions.}

Read at a Meeting of the Institution of Surveyors, N.S.W., Friday, 20th December, 19I8, by Mr. E. H. CowDERY, Vice-President.

The subject of this short paper is the Town Planning aspect of subdivisions, and it is with considerable diffidence that I come before such a body of experts, and with small hope of being able to tell you anything that you don't know. At any rate I am quite sure that there will be at least some among you who will go away quite satisfied in your own minds that you know a good deal more of the subject than the author of this paper.

In order to make myself clear I have had prepared some lantern slides with which to illustrate my subject.

First I have taken quite at random an area in my own Municipality of Burwood which is quite typical of hundreds of others in our suburbs. The area is about 20 acres, and is shown as subdivided in an irregular and piecemeal manner as shown (Slide r). A great diffculty of course had been that the land was originally held in three

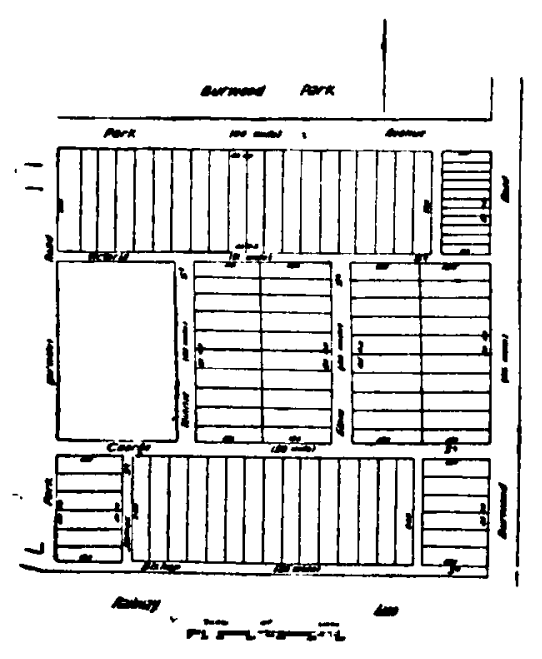

separate areas, and that each owner made his subdivision without reference to adjoining blocks, and of course without taking into consideration in any respect Public convenience. I hope to be able to show that both these matters might have claimed attention with considerable profit of the subdividers.

The allotments, you will see, are not illiberal in depth, but in fact are wasteful in this respect. Lots of a great depth in a residential 
locality are not only not necessary but are liable to be untidy and neglected as to the back yards. What can look worse than a yard encumbered with rubbish and overgrown with all sorts of weeds, the breeding ground of slugs and snails and vermin of all sorts, and a continual nuisance to the neighbours who take pride in their lawns and gardens. A smaller yard is easier kept in order. Of course Burwood is a well-governed Municipality, and such things are not allowed to exist as would be detrimental to public health. In the subdivision fronting Park Road an attempt was made to utilise as a frontage the narrow street 2 I feet wide known by the grandiose name of Victoria Street. Her late Majesty would no doubt have been proud to know of the distinction conferred upon her. This attempt fortunately failed as no one at that date was prepared to build facing such a narrow street. With regard to Bishop Street, however, a number of residences are built fronting what is only a lane. You will see that the streets in the alea are narrow with the exception of Burwood Road and Park Road. George Street which carries a considerable amount of traffic is only 33 feet wide, and I am sure you will agree with me that this is not enough.

I will now try to show what could have been done in the area if there had been co-ordination between the property owners on the one side and the Municipal authority on the other. In the area in question, of course, there was no municipal authority when the injury was done, and even under present conditions the Municipality has little discretion in such a matter. The difficulty can only be overcome by the necessary legislation by which each Municipal area will be able to plan ahead for the future. A plan of each municipal area should be prepared showing, especially in unoccupied lands, at least the main radical and circumferential roads. The details could be arranged later as necessity arose.

In this matter of pre-planning it is very necessary that the members of our profession should make a study of the guiding principles necessary. They should be employed by the Local Authority to advise them in this work, and in order to be able to advise rightly they should know the essentials of a well-planned town. For instance if a railway station is in existence or is to be provided, this will become a centre. Close round this centre will be built shops and business premises. From this centre proper and convenient roads of access should be provided to outlying localities and then the residential areas linked up. The usual chess board design is quite inadequate for modern conditions. Unless the surveyor is willing to be relegated to the position of carrying out the designs of others he must wake up to the necessity of equipping himself with the knowledge required. Town planning is right here and there is no time to waste. Legislation is very close to being an accomplished fact.

These remarks apply also to the Department of Lands, which is quite often engaged in the layout of new towns, and villages. The methods of our District Surveyors need drastic revision. I am glad to notice that some of them are beginning to see the necessity and benefit of the newer ideas. 


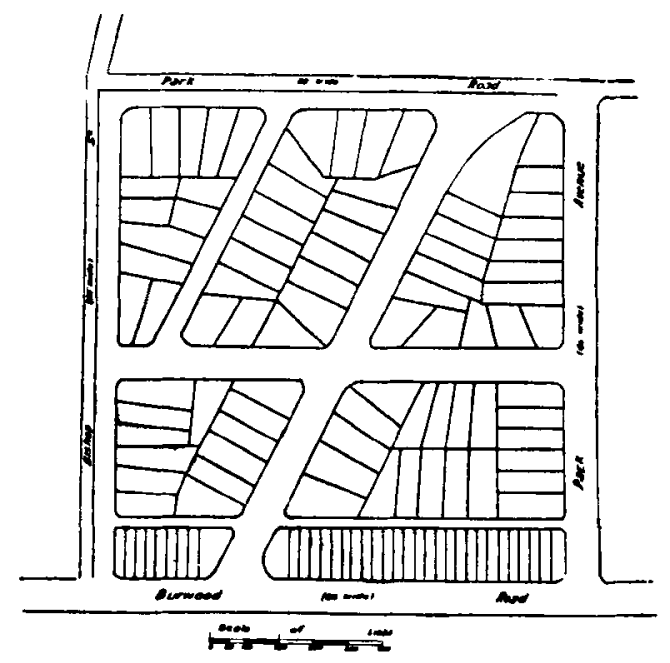

I now show on the screen a proposal for dealing with the ro acres in a reasonable manner. You will see the main feature is a road which would traverse the land from North-West to South-East. This would make practically direct access from the area lying to the North-West of the subject land to the Railway Station by a road not less than one chain wide. The saving in distance for anyone travelling from the intersection of Park Road and Park Avenue to the Railway Station would be 130 yards. Does it not seem reasonable that the public authority should have some say in a matter where the convenience of the people is affected to an extent that every traveller is forced to cover a greater distance by one-third every time his business or convenience caused him to go to such a centre as the Railway Station? This road would benefit in the matter of the proximity to the Railway centre a large number of the allotments in the subdivision.

Now for the benefit to the subdividers I find on examination that the total selling frontage in the area as originally subdivided was about 4.475 feet, and the number of allotments 91 residential, and 43 business sites. In the new design with allotments of a similar frontage of 40 each there would be 5,270 feet frontage in 130 residential sites, and 38 business sites. There would therefore be 795 feet more saleable frontage to good wide streets, and I think you will agree the land under such conditions would be more valuable. In the old subdivision some of the lots on the Northern side of George Street have been turned round and a terrace of houses, and some cottages front the back yards of the allotments fronting Bishop Street. In my design I have provided many allotments with 50 feet frontages, which would not be extravagant in what should be a very desirable situation. I estimate that the land would be increased in value at least ten per cent., and with the increase in the selling frontage of I8 per cent., there would be an addition to the selling price of 28 per 
cent. You will probably agree with me that the subdividers would have suffered no injury, but rather have greatly benefited if the Municipal Authority had possessed. and used the power to control the planning of the area.

Of course there are difficulties in the way. One owner may wish to subdivide and sell, and another to hold his land for his own use, but these matters could be adjusted, and portion only of a plan carried out at a time. The great thing would be for an owner or purchaser of any block of land to know that certain roads of public necessity or convenience would be required in case of subdivision. Does not such a subdivision as that shown on the design appeal to you as one that would be of great permanent benefit.

You will notice on the design one street which is only forty feet wide. In my opinion there should be no objection to this for a short length of street, with only residences to consider, provided the houses are kept back on both sides a sufficient distance to allow for the necessary air space. Such streets are only used by the butcher and baker, and have little or no through traffic. The treatment of these streets is another and important matter which I propose to deal with later on.

I now wish to show you a plan of a proposed subdivision in an adjoining area quite close to a Railway Station. It was in the first place requested that a plan be prepared on Town Planning lines, and this design was submitted. You will see that the main ideas were to provide short access to the Railway Station, where most traffic always gravitates, and to provide allotments having no side lines along the streets. I think you will agree that the design fills the bill. For reasons not stated however, this design was rejected, and

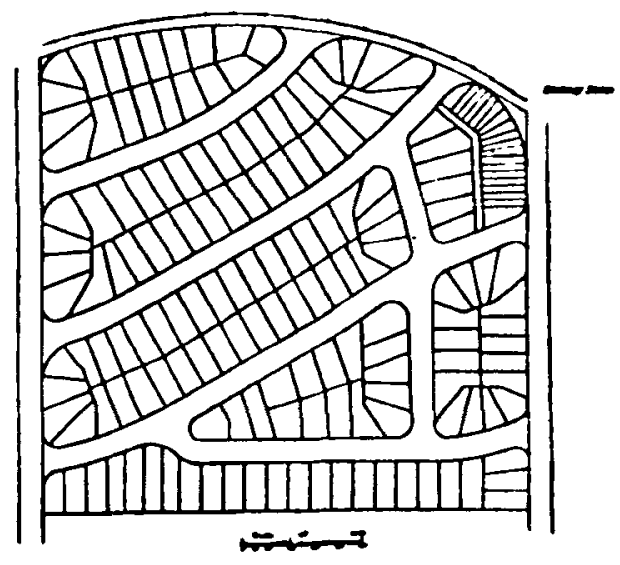

the one shown on this slide substituted. You will perhaps have heard of the small boy, who was asked what salt was, and his reply that salt was what spoiled the porridge when there wasn't any in it. Now, it seems to me that a little of the salt of imagination is 
necessary in considering any design for subdivision. There is not much imagination about this design which is the usual stereotyped arrangement of rectangular allotments. The Public Convenience is not studied, and I hope that you will agree with me that value is sacrificed when purchasers are asked to walk considerably longer distances in going to and from the railway station. The distance from the South-eastern corner of the estate to the railway station is about 140 yards nearer by the rejected design than by the shortest route on the one adopted. This entails a waste of time and effort which, when multiplied by all the passengers who will eventually use the route-well, I will leave it to your imagination. When I tell you that the rejected design provided for more than 2,000 feet extra selling frontage you will wonder why it was thrown out. The reason may have been an objection to a number of irregular shaped lots, but surely want of exact uniformity, and a change from regular monotony should be welcomed.

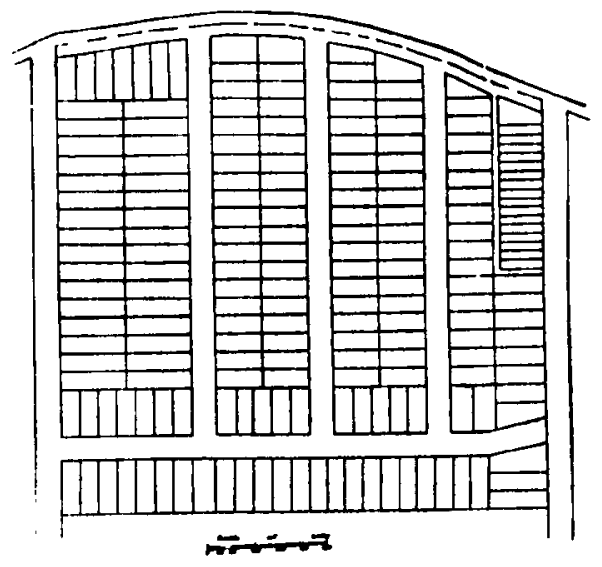

The manner in which irregular shaped lots may be utilised is shown on this slide prepared by Mr. Scott Griffiths, one of our noted town planners. You will notice the corner allotments and the adjustments of the buildings on them. There are no side fences stretching in all their ugliness long distances along the streets, and spoiling to a large extent the outlook from the opposite side of the road. The houses are designed to be what is called demi-detached. This I know is objected to in some districts, but considering the necessity of housing our artisans, and labouring classes, and the great cost of building, I think that under certain conditions this economy could be allowed without detriment. As long as the air space is sufficient round the two houses together, there should be no objection to one wall properly built being used by both premises.

Mr. Griffiths demonstrated in a paper read at the Adelaide Conference how even the rectangular form of subdivision could be improved by thoughtful treatment. This slide was prepared for that purpose. The depths of the allotments have been reduced (they were 
originally too liberal), and a children's playground introduced with foot passengers' recess ten feet wide. In this case more feet frontage was made available, more allotments and also the playground provided. The question of course arises as to whether it could not have been better to place the playground along the centre of the street in front of the allotments with a narrower roadway on each side.

Closely allied to the question of planning is that of road treatment and subdividers in my experience are often so frightened of the expense imposed that good access roads are rejected from the plans, though not seldom these roads would be of great public convenience. This is a matter that requires grave consideration by the Municipal authorities, and where the traffic to be expected is only very light a much narrower roadway than that generally asked for by the Municipalities could be safely accepted. Mr. Griffiths on this diagram shows how he would treat a first-class street with considerable traffic. The carriageway would be 76 feet wide with two six feet footways along the building lines, and $I_{4}$ feet of parkway, trees and grass on each side of the road. This width of roadway is ample for almost any suburban road carrying heavy traffic. For purely residential areas they might easily be reduced to 20 feet from kerb to kerb. and the balance added to the parkways. Some of our local engineers say that the trees should not be placed as shown, but along the roadway with the kerbing along the edge of the footpath. I do not at all agree with this. The kerbing should be as shown forming a protection to the trees and to the grass. This slide also prepared by $\mathbf{M r}$. Griffiths shows the ordinary treatment of the same area as that shown on the last slide. There is not much imagination about this. It is ugly and wasteful. This also applies to the treatment of the road. Here you see the ordinary ugly, and wasteful manner of doing the work. 42 feet between the kerbs and 12 feet footpaths. Below is shown an attempt to plant trees along the footpath taking 6 feet for the purpose. This of course, is quite inadequate, and the cost of road building is excessive. I am glad to say that some Municipal Engineers are beginning to have glimmerings for reform in this direction. My friend Mr. Goodwin the Borough Engineer of Ashfield, and an enthusiastic tree planter of long standing is quite in agreement with me in this matter of the treatment of the roads. Of course, there is not only the saving in the first cost of construction, but also in the never ending cost of maintenance. It may seem a counsel of perfection, but $I$ hope the day is not far distant when all our roads will be coated with tarred blue metal.

In our climate all our wider roads except perhaps where business premises are erected should be planted with trees and where possible the spaces between properly grassed. This with the narrower roadway tar metalled would reduce the dust nuisance to a minimum to the greater comfort and joy of our housewives, and to the benefit of our health. These two things of course go together. To keep the parkways as they are called in proper order in the summer time it is necessary to use water. This question of water supply is a burning one in the Metropolitan area at the present time. Our parks and gardens are all suffering from the inability of Parliament, and the Water Board to give us the storage, and delivery works for the ade- 
quate supply so necessary in our climate. Now as to the cost of survey in the designs shown. I have not had sufficient experience of curved allotment boundaries to be able to make a safe estimate. Our scale of fees provides for Ioo per cent. increase in each allotment with a curved boundary. Whether this will prove to be sufficient to adequately satisfy the increased labour in the field, and in the office time will surely tell. In any case I am satisfied that the increased public benefit will justify the alteration in our general scheme of town planning, and after all it is the Public interest which must come first into our consideration. The benefit is worth paying for.

\title{
Pioneer Surveyors of New South Wales.
}

\author{
By John WeIngarth, I.S. \\ GEORGE WII.LIAMI EVANS \\ (Continued).
}

The following diary of Evans' journey is copied from the Historical Records ; the field books of his survey are not available but the plan plotted and drawn by him from that survey is in the Lands Department.

\section{The Journal of Assistant-Surveyor EVANS}

To His Excellency Governor MACQUARIE, etc., etc., etc.

$$
\text { Saturday, May r } 3 \text { th, I8I5. }
$$

I should have left Bathurst yesterday; when near ready to go, one of my horses threw his load, which damaged some of his tackling ; repairs being necessary caused my delay until this morning ; my course was S. $30^{\circ}$ W. or thereabouts along the fine flat named Queen Charlotte Vale. I halted near the junction of it with the main Creek, which bears S. $20^{\circ} \mathrm{W}$., having plains on both sides; the Vale is also clear of timber ; this day's journey is over exceeding good land, well watered; distance from the Flag Staff eight and a quarter miles. 